\title{
Evaluation of Tanzania local ceramic raw materials for high voltage porcelain insulators production
}

\section{(Avaliação de matérias-primas cerâmicas da Tanzânia para produção de isoladores de porcelana de alta tensão)}

\author{
B. Ngayakamo ${ }^{1 *}$, S. E. Park ${ }^{1 \#}$ \\ ${ }^{I}$ The Nelson Mandela African Institution of Science and Technology, \\ Department of Materials Science and Engineering, Arusha 447, Tanzania
}

\begin{abstract}
This study evaluated the potential of locally sourced-ceramic raw materials in Tanzania, Pugu kaolin, Same clay, vermiculite and feldspar, for production of high voltage porcelain insulators. The chemical, mineral phases and microstructural characterization of raw materials and porcelain samples were carried out using the X-ray fluorescence, X-ray diffraction, and scanning electron microscopy techniques, respectively. The mineral phases of the fired porcelain sample identified were mullite and quartz. The porcelain bodies were fabricated using the dry pressing method by varying the composition of the selected ceramic raw materials. The physicalmechanical properties and dielectric strength were measured for each porcelain sample. The sample with the composition of $20 \%$ Pugu kaolin, 20\% Same clay, 20\% vermiculite and 40\% feldspar was found to have the dielectric strength of $50.8 \mathrm{kV} . \mathrm{mm}^{-1}$, bending strength of $20 \mathrm{MPa}$ and water absorption of $0.46 \%$, which satisfies the main requisite properties for high voltage porcelain insulators Keywords: vermiculite, porcelain insulator, physical-mechanical properties, dielectric strength.
\end{abstract}

\section{Resumo}

Este estudo avaliou o potencial de matérias-primas cerâmicas de origem local na Tanzânia, caulim Pugu, argila Same, vermiculita e feldspato, para a produção de isoladores de porcelana de alta tensão. As caracterizações química, de fases minerais e microestrutural das matérias-primas e amostras de porcelana foram realizadas utilizando as técnicas de fluorescência de raios X, difração de raios $X$ e microscopia eletrônica de varredura, respectivamente. As fases minerais da amostra de porcelana queimada identificadas foram mulita e quartzo. Os corpos de porcelana foram fabricados utilizando o método de prensagem a seco, variando a composição das matérias-primas cerâmicas selecionadas. As propriedades físico-mecânicas e a rigidez dielétrica foram medidas para cada amostra de porcelana. A amostra com composição de $20 \%$ de caulim Pugu, $20 \%$ de argila Same, $20 \%$ de vermiculita e $40 \%$ de feldspato

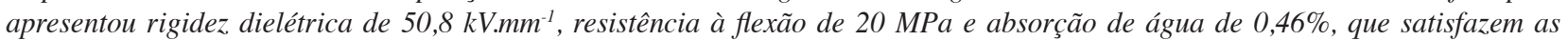
principais propriedades necessárias para isoladores de porcelana de alta tensão.

Palavras-chave: vermiculita, isolador de porcelana, propriedades físico-mecânicas, rigidez dielétrica.

\section{INTRODUCTION}

Porcelain is a ceramic body achieved by firing clay raw materials in the furnace at high temperatures ranging from 1200 to $1400^{\circ} \mathrm{C}$ [1]. Porcelain toughness, strength, and translucence are due to the formation of glass and the mullite phase within the fired porcelain body. Porcelain is principally produced with clay, quartz and feldspar, each material playing a specific role in porcelain structural properties. Clay $\left[\mathrm{Al}_{2} \mathrm{Si}_{2} \mathrm{O}_{5}(\mathrm{OH})_{4}\right]$ gives plasticity, quartz $\left(\mathrm{SiO}_{2}\right)$ maintains the shape of the ceramic structure during firing, and feldspar $\left[\mathrm{K}_{\mathrm{x}} \mathrm{Na}_{1-\mathrm{x}}\left(\mathrm{AlSi}_{3}\right) \mathrm{O}_{8}\right]$ lowers the melting point and influence vitrification of the ceramic structure $[2,3]$. Porcelain insulators are commonly used for electrical devices in power transmission system due to their high dielectric strength and mechanical properties [4]. These are the fundamental reasons for their persistent application

\footnotetext{
*henryblasius@gmail.com; *eugene.park@nm-aist.ac.tz
}

over the centuries regardless of the rise of new materials like polymers, glasses and composites. Porcelain insulators present a huge base of frequently used insulators for both low and high-stress insulation application [5]. Porcelain insulators play an important role in withstanding electrical stress which may result from the working voltage and lightning that may cause flashover on insulators under harsh environmental conditions [6]. For the electrical insulation application, the most required properties are the dielectric and mechanical strength [7]. Dielectric strength measures the ability of an insulator to withstand large electric field strength without electrical breakdown. For high-tension electrical insulation, the dielectric strength has to be greater than $30 \mathrm{kV} / \mathrm{mm}$ [8].

Tanzanian clay deposits have been reported in several places including Pugu-Dar es Salaam, Malangali-Iringa, Matamba-Mbeya and Same-Kilimanjaro [9, 10]. Pugu kaolin, Same clay, vermiculite, and feldspar are locally available ceramic raw materials in Tanzania. Much about physical and 
chemical properties have been reported in the literature [916] as well as their suitability for the production of ceramic tiles [14, 17-19]. However, less is reported and achieved in East African countries about ceramic raw materials for the production of high voltage electrical porcelain insulators $[2,11]$. Moyo and Park [11] characterized the ceramic raw materials from Tanzanian deposits in order to investigate their potential as raw materials for the production of electrical insulators. The electrical insulation and bending strength were observed to increase with the reduction of Kilimanjaro quartz content. The authors reported that increasing Pugu kaolin beyond $48 \%$ and reducing Kilimanjaro quartz content below $6 \%$ led to the reduction of electrical insulation and bending strength. However, the composition of $48 \%$ of Pugu kaolin, $46 \%$ feldspar and $6 \%$ quartz gave the highest strength of 53.5 $\mathrm{MPa}$ and the insulation resistance of $34812 \mathrm{M} \Omega$ at injection of $1000 \mathrm{~V}$. The study showed that high-quality electrical insulator may be achieved from Tanzania originated ceramic raw materials. Olupot [2] assessed the ceramic raw materials in Uganda for electrical porcelain production. The effects of composition on porcelain bodies and the sintering temperature between 1175 and $1375{ }^{\circ} \mathrm{C}$ were evaluated. The author reported that electrical porcelain body with composition of $30 \%$ of Mutaka kaolin, $15 \%$ of Mukono ball clay, $30 \%$ of Mutaka feldspar and 25\% of Lido beach flint yields a body with the highest mechanical strength of $72 \mathrm{MPa}$ and dielectric strength of $19 \mathrm{kV} / \mathrm{mm}$ when fired at $1250{ }^{\circ} \mathrm{C}$. The porcelain insulator mechanical and dielectric strengths were found to decrease with the increase of the firing temperature. The author observed the decrease of undissolved quartz, the increase of glass content and development of pores at the high sintering temperature. However, mullite content did not change at temperatures above $1200{ }^{\circ} \mathrm{C}$ though significant changes in mullite crystals morphologies in the sample were observed. Maximum vitrification and small closely packed mullite needles microstructure gave the best mechanical and dielectric strength of porcelain insulators.

A review of the literature showed that less has been achieved to establish high voltage porcelain insulators data despite the availability of local ceramic materials, which are in plentiful supply, the growing demand for high voltage porcelain insulators and the relevance of the porcelain insulators in Tanzania and other East African countries. Tanzania is only manufacturing low voltage insulators at Kilimanjaro Industrial Development Trust (KIDT) while plenty of local ceramic materials are available in the country, which can be developed to meet the local needs. Therefore, this study intends to evaluate Tanzania local ceramic materials for high voltage porcelain insulators production, so as to contribute with high voltage insulators data and to enable their immediate production in Tanzania.

\section{EXPERIMENTAL}

Materials and methods: Pugu Kaolin was collected from the Pugu hills, $35 \mathrm{~km}$ west of Dar es Salaam, Same Clay and feldspar from Same, Kilimanjaro region in the northern zone of Tanzania, and vermiculite samples were collected from Kalalani, $90 \mathrm{~km}$ south-east of Korogwe Tanga, and Mikese at Nyang'wambe village in Morogoro region. Pugu kaolin (PK), Same clay (SC), Kalalani vermiculite (VK) and feldspar (F) were crushed using a Wedag jaw granulator to reduce their sizes; afterward, they were milled using a stainless-steel ball mill for $3 \mathrm{~h}$. The particle size less than $106 \mu \mathrm{m}$ was achieved by using a sieve shaker (AS200 digit, Retsch, Germany). The use of vermiculite was successful in this study regardless of its exfoliation nature, high moisture content and its complication during drying and firing. However, the use was only achieved after vermiculite was crushed and then oven dried at $110{ }^{\circ} \mathrm{C}$ for $48 \mathrm{~h}$ to remove moisture before it was milled to powder form and then used as an additive (20-30 wt $\%$ ) as a quartz substitute in porcelain compositions. The use of vermiculite as an additive was to avoid complications that could occur during the sintering process of the porcelain samples at $1200{ }^{\circ} \mathrm{C}$. The chemical composition of PK, SC, and VK was determined by X-ray fluorescence (XRF) spectroscopy (PANalytical, Minipal4, PW4030, Rh X-ray tube, $30 \mathrm{kV}$, $0.002 \mathrm{~mA}$ ). The powders of all samples with a particle size less than $106 \mu \mathrm{m}$ were analyzed for $15 \mathrm{~min}$. The mineral phase analysis was done using an X-ray diffractometer (D2 Phaser, Bruker, $30 \mathrm{kV} / 10 \mathrm{~mA}$ ). Four porcelain bodies were fabricated following the procedures indicated in Fig. 1 and by varying the compositions of raw materials (Table I). The powder mixtures were wetly homogenized in a laboratory milling jar for $30 \mathrm{~min}$ to obtain the normal size distribution. Afterward, the powder mixtures were uniaxially compacted into a rectangular shape at $10 \mathrm{MPa}$. The molded rectangular specimens with dimensions $160 \times 40 \times 10 \mathrm{~mm}$ were seasoned indoor at a room temperature for 5 days. This was done to remove water at a slow rate enough to prevent shrinkage and cracks that could occur due to rapid drying. The specimens were turned over once per day while drying to prevent warping. The four fabricated rectangular porcelain green bodies were oven dried (10AF-1, Humboldt, USA) at $110{ }^{\circ} \mathrm{C}$ for $24 \mathrm{~h}$. Sintering was done in a box furnace (RHF 14/8 Carbolite, Keison, UK). The dried rectangular porcelain samples were sintered at $1200^{\circ} \mathrm{C}$ for $1.5 \mathrm{~h}$ with a ramp rate of $10^{\circ} \mathrm{C} / \mathrm{min}$. After firing the sintered porcelain samples were left to cool to room temperature.

Table I - Porcelain formulations (wt\%).

[Tabela I - Formulações das porcelanas (\% em massa).]

\begin{tabular}{ccccc}
\hline Sample & $\begin{array}{c}\text { Pugu } \\
\text { kaolin }\end{array}$ & $\begin{array}{c}\text { Same } \\
\text { clay }\end{array}$ & Vermiculite & Feldspar \\
\hline P-1 & 30 & 0 & 30 & 40 \\
P-2 & 0 & 30 & 30 & 40 \\
P-3 & 20 & 20 & 20 & 40 \\
P-4 & 50 & 35 & 0 & 15 \\
\hline
\end{tabular}

Physical-mechanical properties measurement of porcelain samples: all porcelain samples were subjected to water absorption, apparent porosity, bulk density, linear 


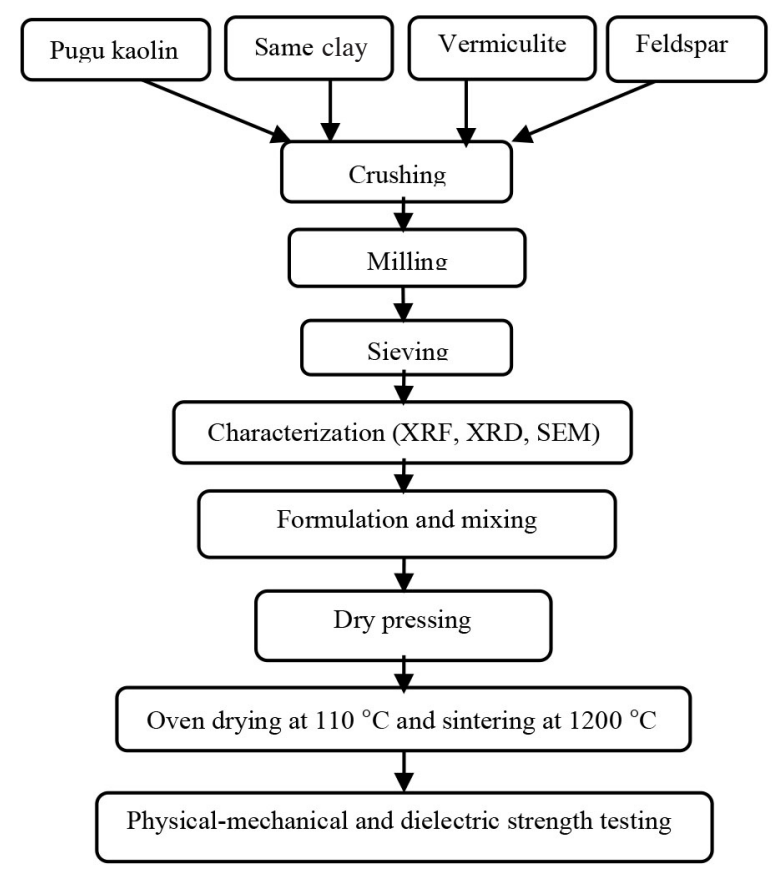

Figure 1: Flow diagram for porcelain samples production.

[Figura 1: Diagrama de fluxo para produção de amostras de porcelana.]

shrinkage, bending and dielectric strength testing. Physical properties measurement: water absorption, porosity and bulk density test was performed on porcelain samples fired at $1200{ }^{\circ} \mathrm{C}$ using a standard method (ASTM C373-88). Bending strength: was measured using bending strength tester (Mega 10-200-10 DS, Prufsyteme, Germany). The bending strength tester was calibrated by Tanzania Bureau of Standards (TBS). Bending strength results were obtained by a three-point testing. The load was applied uniaxially on porcelain rectangular samples until failure occurred. The manometer readings were recorded in $\mathrm{MPa}$.

Dielectric strength measurement: the dielectric strength test was done using a calibrated DC high voltage tester (Megger 220163-47, Biddle Instr., USA) having a maximum output voltage of $160 \mathrm{kV}$. During dielectric strength measurement, a voltage was applied across the sintered ceramic body using two electrodes at the rate of $1 \mathrm{kV} / \mathrm{s}$ until a cracking sound was heard from the porcelain sample. The reading for each porcelain sample was recorded in $\mathrm{kV} / \mathrm{mm}$. Surface morphology analysis: the examination of surface morphology was done by scanning electron microscope (SEM, JSM-6335F, Jeol) at $2 \mathrm{kV}$.

\section{RESULTS AND DISCUSSION}

Characterization of the raw materials: the XRF spectroscopy results revealed that all raw materials had a higher content of silica than alumina in their composition (Table II). Same clay and feldspar had considerable higher content of alkaline oxide, $\mathrm{K}_{2} \mathrm{O}$, than other deposits. The compounds with alkaline oxide $\left(\mathrm{K}_{2} \mathrm{O}\right.$ and $\left.\mathrm{Na}_{2} \mathrm{O}\right)$ from Same clay and feldspar melt at relatively low temperature, and acts as a fluxing agent and assist in liquid phase formation. During the sintering process, these compounds promote vitrification and densification at higher temperatures due to the formation of a liquid phase. The alkaline oxides $\left(\mathrm{K}_{2} \mathrm{O}\right.$ and $\mathrm{Na}_{2} \mathrm{O}$ ) play a significant role towards vitrification, phase transformation and mullite grain growth in the porcelain body $[20,21]$, where the presence of feldspar and aluminasilica mixture was observed to enhance porcelain properties. In this study, the high concentration of alkaline oxide $\left(\mathrm{K}_{2} \mathrm{O}\right)$ from Tanzania locally-sourced ceramic raw materials did not affect the physical-mechanical properties of the porcelain insulators rather than facilitating the vitrification of porcelain samples at low firing temperature, which minimized energy consumption during the sintering process. In order to achieve accurate technological properties of porcelain insulators, such as water absorption, firing shrinkage and bending strength, it is imperative to suppress open porosity and reduce the closed porosity of the porcelain insulators after firing [22]. Maximum vitrification may be achieved by the use of high concentration of potassium oxide or feldspar which form a liquid phase at a relatively low firing temperature [23]. Therefore, the use of high content of potassium oxide may be preferred due to its ability to achieve vitrification at low firing temperature, compared to that recommended for porcelain wares, and its influence on the formation of mullite and glassy phase, which promoted satisfactory properties of the porcelain insulators fired at $1200{ }^{\circ} \mathrm{C}$ as shown below.

Vermiculite had the higher content of $\mathrm{Fe}_{2} \mathrm{O}_{3}$ (38.24\%) compared to feldspar with $8.08 \%$ and Pugu kaolin with $3.95 \%$. Amount of $\mathrm{TiO}_{2}$ was found to be $3.79 \%$ in feldspar and $3.04 \%$ in vermiculite. According to previous authors $[2,17]$, high content of iron oxide causes bloating effect due to the transformation of $\mathrm{Fe}_{2} \mathrm{O}_{3}$ to $\mathrm{Fe}_{3} \mathrm{O}_{4}$ which affect the physical-mechanical properties of the porcelain wares. However, the deleterious effect of high content of iron oxide was not observed in this study at the sintering temperature of $1200{ }^{\circ} \mathrm{C}$; besides, a significant formation of glassy and

Table II - Chemical composition of raw materials.

[Tabela II - Composição química das matérias-primas.]

\begin{tabular}{ccccccccccccc}
\hline Sample & $\mathrm{SiO}_{2}$ & $\mathrm{Al}_{2} \mathrm{O}_{3}$ & $\mathrm{TiO}_{2}$ & $\mathrm{Cr}_{2} \mathrm{O}_{3}$ & $\mathrm{Fe}_{2} \mathrm{O}_{3}$ & $\mathrm{MnO}$ & $\mathrm{MgO}$ & $\mathrm{CaO}$ & $\mathrm{Na}_{2} \mathrm{O}$ & $\mathrm{K}_{2} \mathrm{O}$ & LOI & Total \\
\hline $\mathrm{VK}$ & 26.3 & 13.0 & 3.04 & 0.20 & 38.24 & 0.19 & 2.90 & 4.85 & 0.06 & 5.85 & 5.37 & 100 \\
$\mathrm{~F}$ & 57.1 & 14.0 & 3.79 & 0.92 & 8.08 & 0.32 & 0.01 & 1.00 & 0.20 & 12.1 & 2.49 & 100 \\
$\mathrm{PK}$ & 60.0 & 30.3 & 0.14 & 0.10 & 3.95 & 0.02 & 0.00 & 0.39 & 0.00 & 2.14 & 2.96 & 100 \\
$\mathrm{SC}$ & 60.4 & 13.9 & 1.22 & 0.00 & 1.40 & 0.00 & 0.00 & 0.00 & 0.04 & 22.6 & 0.44 & 100 \\
\hline
\end{tabular}


mullite phases improved the physical-mechanical and dielectric properties of the porcelain insulators. In fact, the results of the current study are in agreement with the literature which reports that iron oxide may contribute to glassy phase development in the composition of porcelain and glassware [24]. Nevertheless, at higher firing temperatures above $1250{ }^{\circ} \mathrm{C}$, there is a reduction of the iron oxide $\mathrm{Fe}_{2} \mathrm{O}_{3}$ which affect the composition of glassy phase due to the formation of $\mathrm{Fe}_{3} \mathrm{O}_{4}$ [24]. When the structure of the glassy phase is changed due to the reduction of $\mathrm{Fe}_{2} \mathrm{O}_{3}$, it may affect the dielectric strength but not the mechanical strength of the porcelain insulators. Therefore, care should be taken while preparing and sintering porcelain green bodies made from ceramic raw materials with a high amount of iron oxide to avoid deviation of the physical-mechanical properties of the porcelain insulators fired at high temperatures above $1200{ }^{\circ} \mathrm{C}$. On the other hand, vermiculite in this study was merely used as a quartz substitute to reduce amount of free silica $\left(\mathrm{SiO}_{2}\right)$, since the most widely used quartz electrical porcelains have weak strength [25], due to $\alpha$ to $\beta$-phase transformation of the quartz that leads to generation of tensile and compressive stresses, which cause microcracks during sintering process [26]. In addition, due to the low silica content of vermiculite compared to pure quartz, vermiculite has shown to be a promising material to be used for the production of high strength porcelain insulators if it is only used as an additive in the porcelain composition during formulation stage. The results of the chemical composition analysis from the current study are close to those of previous studies which also showed a high fraction of silica and alumina $[11,14,17,19]$.

Mineral phases analysis: the X-ray diffraction patterns of the ceramic raw materials and porcelain sample sintered at $1200{ }^{\circ} \mathrm{C}$ is presented in Figs. 2 and 3, respectively. Pugu kaolin and Same clay sample were found to contain clay mineral kaolinite $\left[\mathrm{Al}_{2} \mathrm{Si}_{2} \mathrm{O}_{5}(\mathrm{OH})_{4}\right]$ and non-clay mineral quartz $\left(\mathrm{SiO}_{2}\right)$. Feldspar consisted of microcline and quartz which showed to be potassic feldspar, while vermiculite in powder form showed the interstratified structure of vermiculite which did not contain a hydrated phase. Therefore, kaolinite was a source of alumina $\left(\mathrm{Al}_{2} \mathrm{O}_{3}\right)$ while quartz was a source of silica $\left(\mathrm{SiO}_{2}\right)$ to form aluminum silicate compound at the end of the sintering process as mullite phase $\left(3 \mathrm{Al}_{2} \mathrm{O}_{3} \cdot 2 \mathrm{SiO}_{2}\right)$, which influenced the mechanical and dielectric strength of porcelain insulator, as justified in Fig. 3 in which the main crystalline phases found were mullite and quartz. However, high content of quartz tends to promote high glassy phase which may be detrimental to
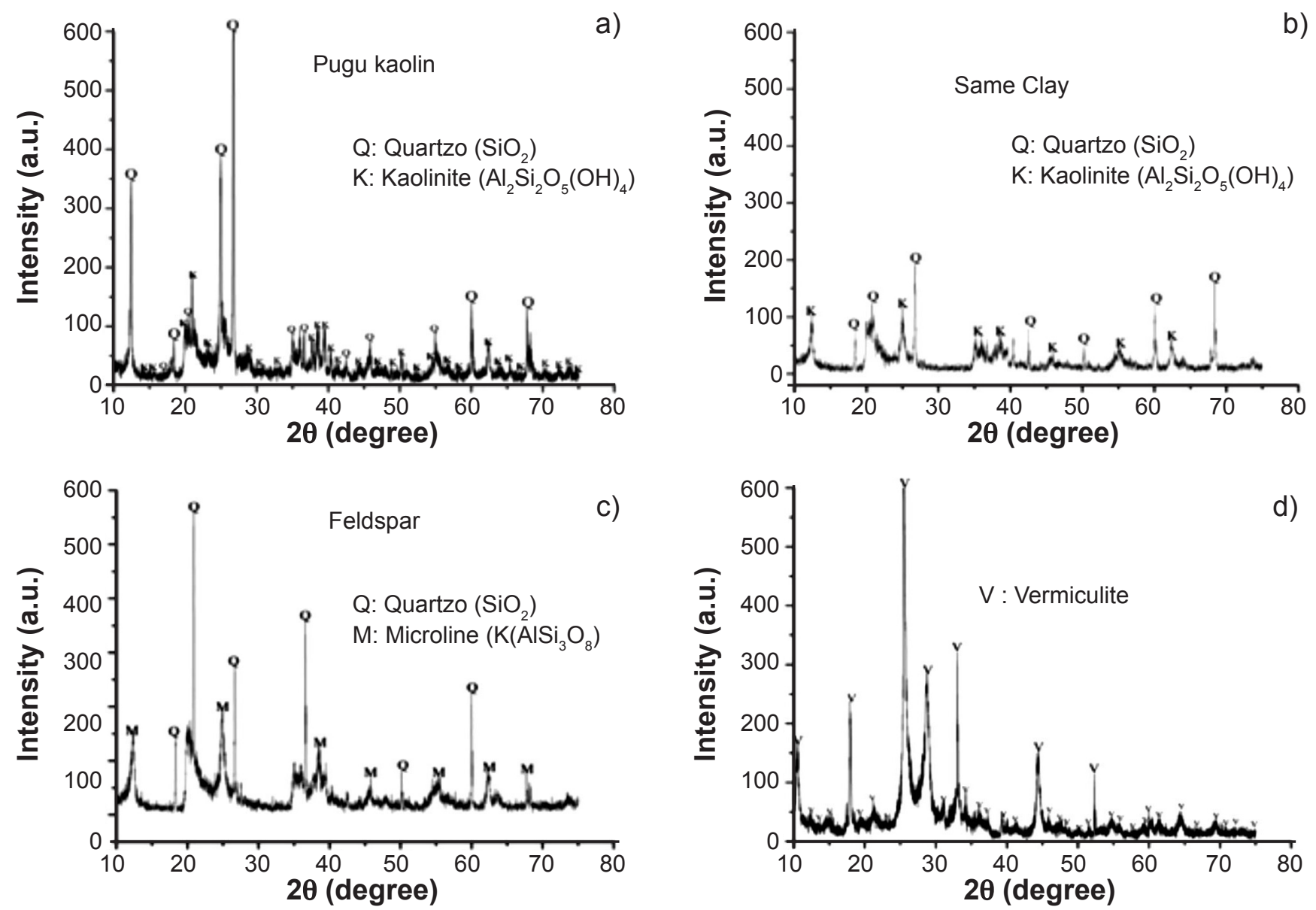

Figure 2: X-ray diffraction patterns of: a) Pugu kaolin; b) Same clay; c) feldspar; and d) vermiculite.

[Figura 2: Difratogramas de raios X de: a) caulim Pugu; b) argila Same; c) feldspato; e d) vermiculita.] 


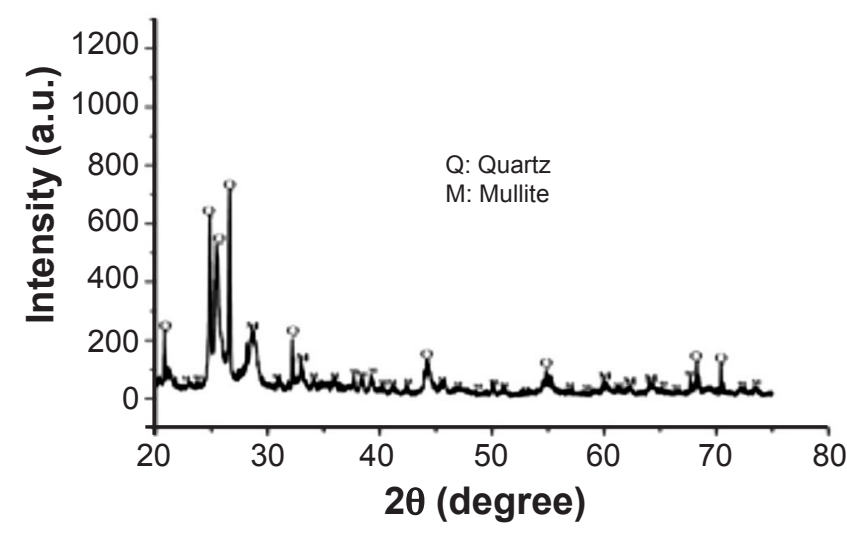

Figure 3: X-ray diffraction pattern of the porcelain sample P-3 sintered at $1200{ }^{\circ} \mathrm{C}$.

[Figura 3: Difratograma de raios $X$ da amostra de porcelana $P-3$ sinterizada a $1200{ }^{\circ} \mathrm{C}$.]
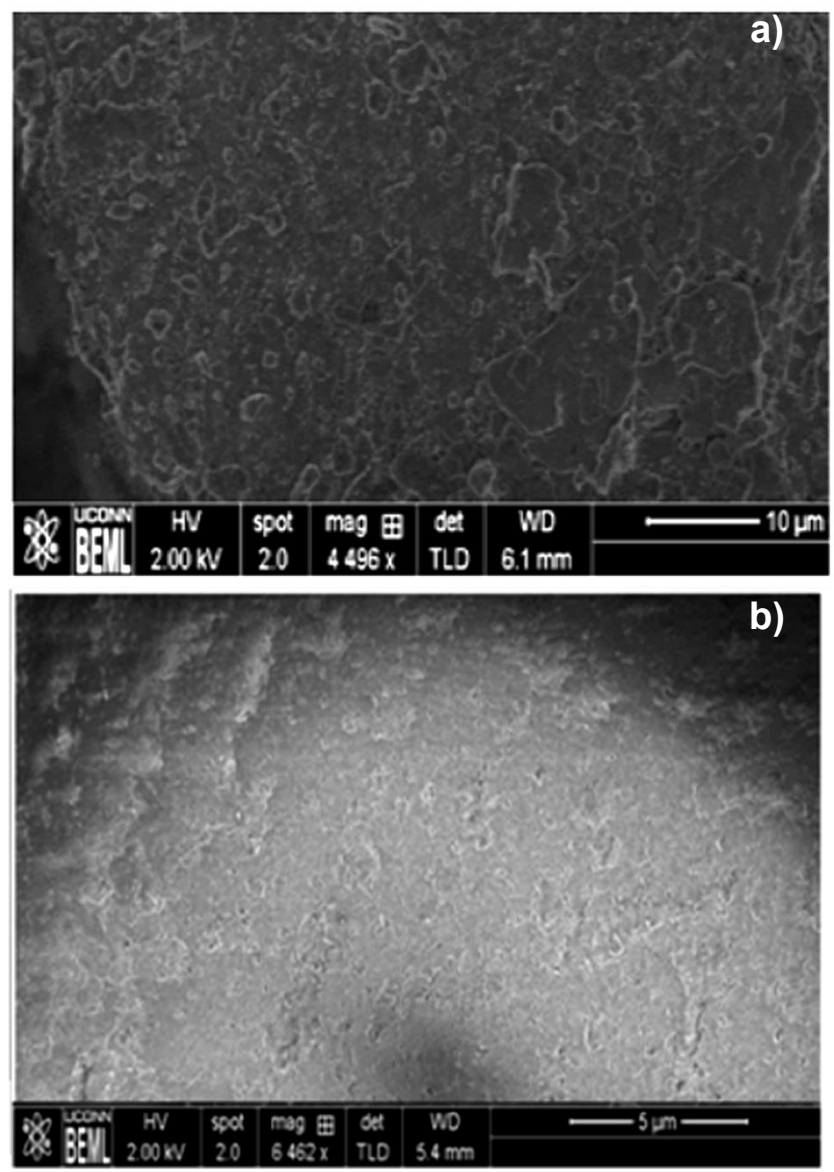

Figure 4: SEM micrographs showing densification of porcelain samples: a) P-1; and b) P-3.

[Figura 4: Micrografias de MEV mostrando densificação de amostras de porcelana: a) $P$-1; e b) P-3.]

the dielectric strength of a porcelain insulator. The glassy and mullite phase $\left.\left[(\mathrm{K}, \mathrm{Na})_{2} \mathrm{O}-\mathrm{Al}_{2} \mathrm{O}_{3}-\mathrm{SiO}_{2}\right)\right]$ promoted maximum vitrification and densification which improved the mechanical and dielectric properties of porcelain samples under study. Surface morphology analysis: Fig. 4 evidences the densification of the porcelain samples P-1 and P-3 after the sintering process was completed.
Physical-mechanical and dielectric properties of fired porcelain samples: the results for water absorption, apparent porosity and bulk density of porcelain samples are shown in Fig. 5. The porcelain samples P-1 and P-3 had low water absorption, low porosity, and higher bulk density values. This might be due to a high concentration of feldspar which melts and contributes to the formation of the liquid phase. The liquid phase formed during sintering fills the pores thus blocking the open porosity, increase the density and decrease water absorption. The trend of the results was in agreement with other works $[17,19]$. The authors reported that high percentages of feldspar result in enough liquid phase, which fills the open porosity, decreases water absorption and increases bulk density, while low feldspar content results in opposite effects. The porcelain samples P-1 and P-3 had the lowest water absorption values (0.45\%-0.48\%) which were within standard requirements for porcelain wares, less than $0.5 \%$ as recommended by ISO-13006. The bulk density results for porcelain samples P-1, P-3 and P-4 were within established standards for porcelain body (1.71-2.1 $\mathrm{g} / \mathrm{cm}^{3}$ ) [27]. The bulk density of porcelain sample P-2 was low regardless of having high percentages of feldspar. This might be caused by the development of closed pores which affected densification of the porcelain sample structure.

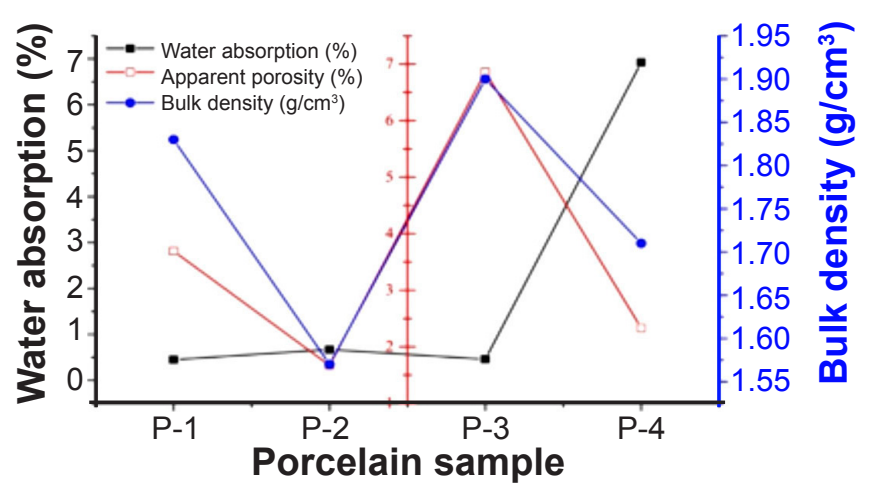

Figure 5: Water absorption, apparent porosity and bulk density of porcelain samples.

[Figura 5: Absorção de água, porosidade aparente e densidade aparente das amostras de porcelana.]

Results of linear shrinkage for porcelain samples are shown in Fig. 6. The porcelain sample P-3 exhibited higher shrinkage value as it was highly vitrified compared to porcelain samples $\mathrm{P}-1, \mathrm{P}-2$ and $\mathrm{P}-4$. This trend might have been caused by optimum vitrification which densified the porcelain structure and reduced its size. This was due to the high concentration of feldspar in the composition, which promoted maximum vitrification range in the porcelain sample $\mathrm{P}-3$. The results are in agreement with the literature [19]. The author reported that feldspar plays the role of the fluxing agent in porcelain body thereby help to increase vitrification and shrinkage. Optimum vitrification is achieved in ceramic when there is maximum linear shrinkage [28]. The lowest linear shrinkage in P2 was due to an absence of Pugu kaolin and low concentration of feldspar 
in the composition. The liquid phase formed by Pugu kaolin may be responsible for blocking the open porosity leading to decrease in shrinkage [29]. The low linear shrinkage indicates the good stability of the porcelain structure. On the other hand, high shrinkage may cause cracking of the porcelain wares resulting in a reduction of the strength.

The results for bending strength are also shown in Fig. 6. The porcelain samples P-1 and P-3 exhibited higher values of strength than the porcelain samples P-2 and $\mathrm{P}-4$. This was due to the fact that the porcelain sample P-3 was highly vitrified and densified with the absence of microcracks which made the bending strength of P-3 sample to be high. This was caused by high concentration feldspar and potassium oxide from locally-sourced ceramic raw materials which melted and formed a liquid phase. The liquid phase formed filled the pores, decreased the porosity and promoted vitrification and densification and the strength of porcelain samples. The porcelain samples P-2 and P-4 had low strength values due to low feldspar content and presence of microcracks which affected the strength of porcelain samples. The results of the current study are in agreement with other works $[17,19,30]$. The authors reported that mechanical strength increased with high feldspar content in porcelain samples. High feldspar content influences formation of the liquid phase which fills the pores which eventually decreases porosity and increases mechanical strength. Theoretically, a maximum flexural strength may be obtained when the apparent porosity decreases to zero [31]. According to ISO-13006 the minimum bending strength recommended for porcelain insulators and other porcelain wares is $35 \mathrm{MPa}$. Therefore, the bending strength value achieved for porcelain sample P-3 was close to the value recommended by ISO-13006 compared to other porcelain samples in this study.

The results for dielectric strength of porcelain samples with different compositions are shown in Fig. 6. The best value for dielectric strength was exhibited by P-3. The values of porcelain samples $\mathrm{P}-1, \mathrm{P}-2$ and $\mathrm{P}-3$ exceeded

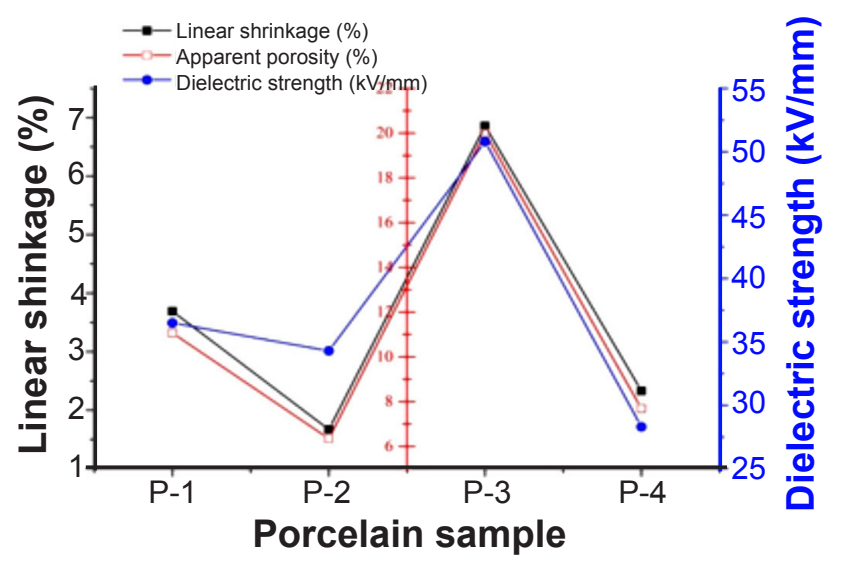

Figure 6: Linear shrinkage, bending strength and dielectric strength of porcelain samples.

[Figura 6: Retração linear, resistência à flexão e rigidez dielétrica das amostras de porcelana.] the dielectric strength value of $30 \mathrm{kV} / \mathrm{mm}$ for high tension electrical insulation [8]. This might have been caused by high vitrification achieved by the samples at the end of the firing process. The liquid phase formed during sintering promoted proper filling of the pores and increased densification which influenced the high dielectric strength of porcelain sample P-3. In contrast, the counterpart sample P-4 had low dielectric strength due to its low vitrification. Low vitrification failed to suppress and reduce closed porosity during firing which caused low densification and later low dielectric strength. This was reported in [4]. The author reported that porcelain insulators with 20-30\% amount of feldspar had the optimal dielectric strength while those with $15 \%$ amount of feldspar had low values of dielectric strength. Low concentration of feldspar results in poor vitrification leading to a low glassy phase which may affect the dielectric strength of the porcelain insulator.

\section{CONCLUSIONS}

The results of the study presented in this work showed that Tanzania ceramic raw materials have the potential for production of high voltage porcelain insulators. It has been found that the porcelain sample (P3) with composition of $20 \mathrm{wt} \%$ of Pugu kaolin, $20 \mathrm{wt} \%$ of Same clay, $20 \mathrm{wt} \%$ of vermiculite and $40 \mathrm{wt} \%$ of feldspar had the dielectric strength of $50.8 \mathrm{kV} \cdot \mathrm{mm}^{-1}$, bending strength of $20 \mathrm{MPa}$ and water absorption of $0.46 \%$ after firing at $1200{ }^{\circ} \mathrm{C}$ which are the main requisite properties for making high voltage porcelain insulators. However, porcelain samples were found to have a high porosity which might be caused by the method of production of porcelain samples adopted. The results of the characterization of the ceramic raw materials showed that vermiculite contained a high content of $\mathrm{Fe}_{2} \mathrm{O}_{3}$. Therefore, careful sintering of the ceramic raw materials and porcelain samples should be done in order to avoid the decrease of dielectric strength due to change in glassy phase structure as the result of the reduction of $\mathrm{Fe}_{2} \mathrm{O}_{3}$ at high firing temperature. Furthermore, the method of production should be improved to remove trapped water bubbles inside the porcelain samples. Hence high-quality porcelain insulators can be achieved from locally sourced ceramic raw materials from Tanzania provided the above recommendations are followed.

\section{ACKNOWLEDGMENTS}

The authors would like to acknowledge the financial support from the British Gas (BG) for funding the scholarship. The sincere gratitude goes to the management of the Nelson Mandela African Institution of Science and Technology (NM-AIST), the Department of Materials Science and Engineering, University of Connecticut in the United States of America, the Geological Survey of Tanzania (GST), Tanzania Twiga Cement Company and Tanzania Electric Supply Company for their maximum cooperation rendered to this work. 


\section{REFERENCES}

[1] A.O. Oladiji, J.O. Borode, B.O. Adewuyi, I.O. Ohijeagbon, J. Res. Inform. Civil Eng. 7 (2010) 47.

[2] P.W. Olupot, "Assessment of ceramic raw materials in Uganda for electrical porcelain", Thesis, KTH, Stockholm, 2006.

[3] W.M. Carty, U. Senapati, J. Am. Ceram. Soc. 81, 1 (1998) 3 .

[4] C.C. Okolo, O.A. Ezechukwu, E.N. Ifeagwu, R.C. Unegbu, Int. J. Eng. Innov. Res. 3, 6 (2014) 877.

[5] L.U. Anih, Niger. J. Techn. 241 (2005) 1.

[6] R.S. Gorur, E.A. Cherney, J.T. Burnham, Outdoor insulators, Ravi s Gorur, Phoenix (1999).

[7] R.A. Islam, Y. Chan, M.F. Islam, Mater. Sci. Eng. B 106 2 (2004) 132.

[8] G. Haertling, R. Buchanan, in Ceramic materials for electronics, Ed. R. Buchanan, Marcel Dekker, New York (1991) 12.

[9] H. Lobitzer, R. Giacomini, H.W. Müller, R. Nötstaller, B. Schwaighofer, Mitt. Ges. Geol. Bergbaustud. Österr. 28 (1982) 1 .

[10] B. Schwaighofer, H. Muller, Clay Miner. 22, 4 (1987) 401.

[11] M.G. Moyo, E. Park, Int. J. Eng. Res. Techn. 3, 10 (2014) 6 .

[12] K. Wiik, L.D. Akwilapo, Bull. Chem. Soc. Ethiopia 17, 2 (2003) 147.

[13] G.-I.E. Ekosse, Appl. Clay Sci. 50, 2 (2010) 212.

[14] H. Hamisi, Int. J. Mater. Sci. Appl. 3, 5 (2014) 143.
[15] H.G. Njau, E. Park, Int. J. Innov. Res. Adv. Eng. 2, 4 (2015) 167.

[16] H.G. Njau, E. Park, Int. Res. J. Eng. Techn. 2, 9 (2015) 13.

[17] L.D. Akwilapo, K. Wiik, Bull. Chem. Soc. Ethiopia 17, 2 (2003) 147.

[18] E. Lugwisha, Tanz. J. Sci. 32, 2 (2006) 69.

[19] V. Kimambo, Int. J. Sci. Techn. Soc. 2, 6 (2014)) 201.

[20] S. Chaudhuri, Am. Ceram. Soc. Bull. 53, 2 (1974) 169.

[21] S.K. Das, K. Dana, Thermochim. Acta 406, 1 (2003) 199.

[22] D. Njoya, F.S. Tadjuidje, E.J.A. Ndzana, A. Pountouonchi, N. Tessier-Doyen, G. Lecomte-Nana, J. Asian Ceram. Soc. 5, 4 (2017) 422.

[23] W. Acchar, E.J. Dultra, Ceramic materials from coffee bagasse ash waste, Springer (2015).

[24] G. El-Damrawi, A.M. Hassan, S. El-Jabal, Glass Ceram. 7 (2017) 13.

[25] A. Sedghi, N. Hamidnezhad, N.R. Noori, in Int. Conf. Ecolog. Environ. Biolog. Sci., Pattaya (2012).

[26] N.R. Noori, R.S. Mamoory, S. Mehraeen, Am. Ceram. Soc. Bull. 86, 3 (2007) 9201.

[27] E. Lugwisha, Tanz. J. Sci. 37, 1 (2011) 167.

[28] J. Martín-Márquez, J.M. Rincón, M. Romero, Ceram. Int. 348 (2008) 1867.

[29] S. Mustafi, Bangladesh J. Sci. Res. 24, 2 (2012) 169.

[30] A. Norris, D. Taylor, I. Thorpe, Trans. J. Br. Ceram. Soc. 78, 5 (1979) 102.

[31] S. Kitouni, A. Harabi, Cerâmica 57, 344 (2011) 453.

(Rec. 19/01/2018, Rev. 10/03/2018, 03/05/2018, 19/05/2018, Ac. 23/05/2018) 